\title{
Otantik Liderlik, Örgütsel Bağlılık ve Psikolojik Sermaye Arasındaki İlişki: Tekstil Sektöründe Bir Uygulama
}

\author{
Relationship Between Authentic Leadership, Organizational Commitment And \\ Psychological Capital: An Application In Textile Sector
}

Mehmet $S A \breve{G} I R *$

Asll Ŭgur AYDIN**

$\ddot{O} Z$

21. yüzyılda örgütlerin başarısı, işgörenlerin sahip oldukları bilgi, beceri ve yetenekleri kullanabileceği, iş tatmin duygularının yüksek olacă̆l, motivasyonlarının yüksek düzeyde olacağı örgütsel iklimin oluşmasına bă̆lıdır. Bu durum, işgörenlerin örgütsel bağlllık düzeylerini artıracağından işgörenlerin amaç ve hedefler doğrultusunda performanslarını da yükseltmektedir. Örgütsel bă̆glliğın artmasında bazı bireysel özelliklerin (psikolojik sermaye) ön plana çıkması gerekmekte ve bunda etkili olacak faktör ise yönetici ve liderlerin tutum ve davranışları olarak karşımıza çıkmaktadır. Otantik liderlik tarzı, bu özelliklerin ön plana çıkmasında etkili bir liderlik tarzı olarak bu özelliklerin (psikolojik sermaye) kazanılması ve geliştirilmesinde etkili olmaktadır. Bu çalışmada otantik liderliğin hem örgütsel bağlllık üzerinde hem de psikolojik sermaye üzerindeki, aynı zamanda psikolojik sermayenin örgütsel bağlılık üzerindeki etkisi ile bu üç değişken arasındaki ilişki araştırlmıştır. Bunlarla birlikte, psikolojik sermaye algısının önemi düşünülerek, demografik özelliklerin psikolojik sermaye algısındaki farklılık ortaya koyup koymadığ araştırılmıştır. AMOS'ta yapılan analizler sonrasında araştırmanın sonucu olarak; Otantik liderliğin hem örgütsel bă̆lllık hem de psikolojik sermaye üzerinde, psikolojik sermayenin de örgütsel bă̆lllık üzerinde pozitif ve anlamlı etkisinin olduğu tespit edilmiştir. Üçlü etki ile birlikte otantik liderliğin örgütsel bağlllık üzerindeki etkisinde psikolojik sermayenin aracılık rolünün olduğu tespit edilmiştir. Yine üç değişken arasında pozitif ve anlamlı ilişki tespit edilmiştir.

ANAHTAR KELIMELER

Liderlik, Otantik Liderlik, Örgütsel Bă̆lllık, Psikolojik Sermaye

\begin{abstract}
The success of organizations in the 21st century depends on the formation of an organizational climate in which employees can use their knowledge, skills and abilities, have high levels of job satisfaction and high motivation. This increases the organizational commitment levels of employees and increases their performance in line with the objectives and targets. Some individual characteristics (psychological capital) need to come to the forefront in increasing organizational commitment and the effective factor for this is the attitudes and behaviors of managers and leaders. Authentic leadership style is an effective way in acquiring and developing these characteristics (psychological capital) as an effective leadership style in bringing these features to the forefront. This study investigates the effect of authentic leadership on both organizational commitment and psychological capital, as well as the effect of psychological capital on organizational commitment and the relationship between these three variables. Furthermore, considering the significance of psychological capital perception, study attempts to examine whether demographic characteristics represent any differences in psychological capital perception. Following the analysis performed on AMOS, it was found that authentic leadership has a positive and significant effect on both organizational commitment and psychological capital and psychological capital on organizational commitment. It has been also determined that psychological capital has a mediating role in the effect of authentic leadership on organizational commitment along with triple effect. Yet again, a positive and significant relationship was found between these three variables
\end{abstract}

KEYWORDS

Leadership, Authentic Leadership, Organizational Commitment, Psychological Capital, Structural Equality

\begin{tabular}{|c|c|c|}
\hline \multicolumn{2}{|c|}{ Makale Geliş Tarihi / Submission Date } & \multicolumn{1}{c|}{$\begin{array}{c}\text { Makale Kabul Tarihi / Date of Acceptance } \\
11.07 .2019\end{array}$} \\
\hline \multirow{3}{*}{ Atıf } & $\begin{array}{l}\text { Sağır, M. ve Aydın, A.U. (2019). Otantik Liderlik, Örgütsel Bağlllık ve Psikolojik Sermaye Arasındaki İlişki: Tekstil } \\
\text { Sektöründe Bir Uygulama. Selçuk Üniversitesi Sosyal Bilimler Meslek Yüksekokulu Dergisi, 22 (2), 800-812. }\end{array}$ \\
\hline
\end{tabular}

\footnotetext{
* Dr. Öğr. Üyesi, Selçuk Üniversitesi Turizm Fakültesi, Seyahat İşletmeciliği ve Turist Rehberliği Bölümü msagir@ selcuk.edu.tr, ORCID: 0000-0002-7081-5462

** Bilim Uzmanı, asliaydin1710@ outlook.com, ORCID: 0000-0002-9354-2591
} 


\section{GİRIŞ}

21. yüzy1lın ikinci döneminde iletişim teknolojilerinin gelişimlerine bağlı olarak meydana gelen yüksek rekabet koşullarında örgütler, yeni ve pozitif yaklaşım sergileyebilen bir liderlik türüne ihtiyaç duymuşlardır. Örgütlerin en genel amaçlarından bir tanesi varlıklarını devam ettirmek ve büyümek olduğundan, büyümenin ve sürekliliğinin sağlanması için etkili bir liderin varlığına ve örgütsel bağl1lık düzeyleri yüksek işgörenlere ihtiyaç duyulmaya başlanmıştır.

Otantik lider, takipçilerinin düşünce ve fikirlerine açık olan, bu şekilde onların yetenek ve diğer özelliklerinin farkına varan dolayısıyla onlarla uyumlu olan bir lider olarak ifade edilirken, takipçilerine güven veren ve geleceğe umutla bakan kişilerdir. Bu durum ve davranışlar içerisinde otantik liderin, liderlik süreci içerisinde kendini geliştirmeyi düşünen ve amaçlarla uyumlu davranış gösterdiği de söylenebilir.

Örgütsel bağl1lık, işgörenlerin örgütsel amaçlar ve değerleri benimsemiş olması, amaçlara ulaşma yolunda kendisini yetkin hissedip motive olmuş bir durumda örgütle arasında oluşan duygusal bir bağdır. Bağl1lığın yüksek düzeyde olduğu işgörenlerin performans düzeyleri üst seviyelerde seyretmektedir. Örgütsel bağl1lı̆̆ın yüksek olması yine bireyin sahip olacağı, kendinin farkında olabilme, gelecekte amaca kolayca ulaşabilme konusunda hem iyimser hem de umut dolu olabilme ve karş1laşılan sorunlarda kırılgan olmadan devamlılık gösterip sorun çözebilecek güce sahip olma, özelliklerine bağlıdır. Bu özelliklerin geliştirilmesi ile örgütsel bağlılık duygusu da artacaktır. Bireylerdeki bu özellikler liderlik tarzına bağlı olarak gelişecek ya da ortaya çıkacaktır. Otantik liderlik tarzı, bu özelliklerin ön plana çıkmasında etkili bir liderlik tarzı olarak bu özelliklerin (psikolojik sermaye) kazanılması ve geliştirilmesinde etkili olmaktadır. İşgörenlerin sahip olduğu öz yeterlilik, iyimserlik, umut ve dayanıklılık bireydeki psikolojik sermaye olarak ifade edilirken, aynı zamanda açık ve paylaşımcı bir örgüt kültürünün gelişmesine katkı yapan otantik liderlik sürecinde de artmaktadır.

$\mathrm{Bu}$ çalışmada genel olarak, örgüt içerisinde otantik liderlik, psikolojik sermaye ve örgütsel bağlılık arasında nasıl ve ne düzeyde bir ilişki olduğu, tekstil sektöründe araştırılmıştır. Bu araştırma amacıyla bakıldığında; araştırmanın sorunsalını, "otantik liderlik örgütsel bağlılık ve psikolojik sermaye arasında nasıl ve ne derece bir ilişki vardır?" Varsa ilişki çerçevesinde; "otantik liderliğin hem örgütsel bağlılık hem de psikolojik sermaye üzerinde, psikolojik sermayenin örgütsel bağl1lık üzerinde, etkileri var mıdır, varsa ne düzeydedir?", "Otantik liderliğin örgütsel bağlılık üzerindeki etkisinde psikolojik sermayenin aracılık rolü var mıdır?" oluşturmaktadır.

\section{OTANTIKK LIDERLIKK}

İnsanların, örgütlenmeye başlamasından günümüze kadar varlığını sürdüren liderlik (Bass ve Steidlmeimer, 1999: 181), uzun bir geçmişe dayanmasına rağmen, akademik anlamda son dönemlerde üzerinde daha çok durulmaya başlanmıştır (Tabak vd. 2010: 92). Liderlik ile ilgili yapılan tanımlara bakıldığında kişilerin bulundukları koşullar neticesinde kavramın da şekillendiği söylenmektedir. Liderlik, İngilizce'de "insanlara yol göstermek" anlamında kullanılan "to lead" kelimesinden gelmektedir (Coşar, 2011: 4;23). Loke'a (2001) göre lider, büyümek, yenilenmek, gelişmek, zorlu firsatları değiştirmek ve yapılan hatalardan ders çıkaran geniş görüş sahibi kişi olarak tanımlanmaktadır. Sert'e (2015: 9) göre lider, farklı amaç ve hedefleri ile diğer işgörenlerden ayrılan, vizyonu ve davranışlarıyla öncü kişilerdir.

Günümüz iş dünyasında liderler kadar liderin etkilediği diğer üyelerinde de aktif olan liderlik bir süreçtir. Belirli bir olayda lider ve üyeler ile gerçekleşen bir etkileşim sonucunda oluşmaktadır (Akgündüz, 2012: 6). Liderlik, örgüt amaçlarına ulaşabilmek adına işgörenlerin yaptıklarını kontrol ederek yönetilmesi davranışı olarak tanımlanmaktadır (Karahan, 2008: 147). Liderlik ile ilgili gelişmeler aşağıdaki gibi açıklanmaktadır (Avolio vd. 2009: 442);

- Bütünselliğe önem verilmektedir.

- Pozitif ve değer odaklı yaklaşıma sahiptir.

- Karmaşık olduğu kadar dinamik bir yapıya sahiptir.

- İşgörenler önemsenmektedir.

- Liderlik ile ilgili yapılan çalışmalar liderliğin önemini arttırmaktadır.

Özellikle liderlik kavramı ile ilgili yapılan çalışmalar, liderliğin türü ve sürecinin anlaşılmasında önemli bir yere sahiptir. İşgörenlere yol göstermek olumlu bir durum olsa da bazı liderlik türlerinde bu durum olumsuz davranışların da oluşabilmesine sebep olmaktadır. Olumlu liderlik türlerinden otantik liderlik tamamen insan odaklı bir yapıya sahip olduğundan üzerinde durulması gereken liderlik türlerinin başında gelmektedir.

1990'lı y1llarda ortaya çıkan ve liderlik kavramına farklı bir boyut kazandıran otantiklik, bireyin rutin işlerinde değer, tercih ve gereksinimlerinde kendi doğrularını uygulaması olarak tanımlanmaktadır (Kernis, 
2003: 13-14; Chan vd. 2005). Özgüvenli, umutlu, optimist, ahlaki nitelikleri benimseyen ve vizyon sahibi olan otantik liderler, kendilerinin gelişimlerini önemseyerek pozitif davranışlar sergilemektedirler (Gezer, 2015:17). İzleyiciler ve liderler arasındaki etkili iletişim sonucunda meydana gelen karşılıklı güven ile hem izleyicilerin bireysel anlamda da gelişimin kolay sağlandığ hem de örgütte uyumun arttığ 1 görülürken, böylelikle de performansın yükselmesine sağlanmış olacaktır (Keser ve Kocabaş, 2014: 4). Bu nedenle liderler, kendilerinin ve takipçilerini sürekli öğrenme ve gelişmelerini sağlayan örgütsel bir iklim oluşturmalı ve oluşturulan bu iklimi devam ettirebilmelidirler (Avolio ve Gardner, 2005: 367).

Otantik liderler, işgörenlere ve onların görüşlerine değer vererek işgörenler ile birlikte işbirlikçi bir iş ortamı oluşturmayı amaçlamaktadırlar. Bu sayede işgörenler kendi görüşlerini rahatça dile getirebilecek, herhangi bir durumda işi yürütülmesiyle ilgili fikirlerinin alınması neticesinde kendilerini önemli hissedecek ve örgüte olan bağl1lık düzeyleri de arttırılacaktır. Pozitif bir örgüt ikliminin de oluşmasına katkı sağlayan otantik liderler, işgörenlerin performansının da arttırılmasında büyük rol oynamaktadırlar. Otantik liderlere düşen en büyük görevler arasında kendilerini izleyen işgörenlerin motivasyonlarını arttırmak ve işgörenlerin kendilerini yeterli hissetmelerini sağlamak yer almaktadır. Otantik liderler kendilerinde bulunan dürüstlük, güvenme, karşısındakine karşı açı ve paylaşımcı olma gibi özelliklerini kendilerini izleyen işgörenlere de aşılaması da örgüt için büyük önem arz etmektedir (Topaloğlu ve Özer, 2014: 161-162).

Yapılan alanyazın çalışması sonucunda farklı araştırmacılar tarafından otantik liderlik boyutları benzer kavramlar altında inceledikleri görülmektedir. Kernis (2003: 13-15) öz farkındalık, tarafsızlık, eylem ve ilişkisel oryantasyon, Avolio ve Gardner (2005) ve Walumbwa ve arkadaşları (2008) öz farkındalık, ilişkisel şeffaflık, içselleştirilmiş ahlak anlayışı ve bilgiyi dengeli değerlendirme olarak ele almaktadır. Walumba ve arkadaşları bu bileşenler doğrultusunda Otantik Liderlik Modeli ve Otantik Liderlik Ölçeği'ni geliştirmişlerdir.

$\ddot{O}_{\boldsymbol{z}}$ farkındalık, kişinin kendi duygu, düşünce ve arzuları gibi olumlu ya da olumsuz bütün özelliklerini bilmesi ve doğasındaki zıtlıkların da farkında olması gerekmektedir (Keser, 2013: 31).

İlişkisel şeffaflkk, kişinin o anki durum için duygu ve bilgilerini açık bir şekilde aktarabilmesi yani, kişinin karşısındakilerle kurduğu açık ve dürüst bir şekilde yaptığı iletişim olarak tanımlanmaktadır (Topaloğlu ve Özer, 2014).

İçselleştirilmiş ahlak anlayışı, örgütsel davranış ve kararlara etki eden içsel moral standartların ve moral değerlerin rehberliğinde yön vermek anlamını taşımaktadır (Öcal ve Barın, 2016: 73). Oto-kontrolün bir şekli olan içselleştirilmiş ahlaki bakış açısı, işgörenlerin içinden gelen ahlaki davranışlar ile şekillenmektedir (Walumbwa vd., 2008: 92)

Bilgiyi dengeli değerlendirme, kişinin bilgiye dönük, tarafsız bir tutumda olması gerektirdiğinden bilginin ele alınırken abartılı ve yanlı olmadan doğru ve objektif bir şekilde bilgileri analiz ederek diğer işgörenlerin de fikirlerine önem vermesidir (Walumbwa vd., 2008: 92; Kernis, 2013'den Akt. Keser ve Kocabaş, 2013: 3).

Liderlerin otantiklik özelliğini elde edebilmesi, her türlü eylem ve faaliyetlerinde ahlaki, dengeli ve tarafsız bir şekilde hareket etmesi ile mümkün olabilmektedir. $\mathrm{Bu}$ da, kendisini izleyen işgörenlerin düşüncelerini dinlemeden ve onlara önemli olduklarını hissettirmeden geçmektedir.

\section{2.ÖRGÜTSEL BAĞLILIK}

Örgütün hayatta kalabilmesi ve rakipleri arasında rekabet avantajı sağlayabilmesi, işgörenlerin örgüte sağladığı katkılardan dolayı işgörenlerin işe devamlılıklarının ve bağlılık düzeylerinin nasıl olduğu ile alakalıdır. Ayrıca örgütlerin işgörenlerine önem vermeleri, güvenmeleri ve hayatlarını devam ettirebilmeleri için işgören odaklı yaklaşımda bulunmaları gerekmektedir. Örgütlerin işgörenleri örgütün vazgeçilmez bir parçası olarak göremeyen, onlara bir makinadan farklı olmadıklarını düşündürülmesi işgörenleri örgüt amaçlarının gerçekleştirilmesinde aktif bir rol oynayamaz hale getirmekte ve işgörenlerin kendilerini faydasız ve değersiz hissederek örgüte karşı olumsuz tutum ve davranışlarda bulunmasına sebep olmaktadır (Demirel, 2009).

Çeşitli yöntemlerle işgörenlerin kendilerini değerli hissetmelerini sağlayan örgütlere karşı zamanla bir bağl1lık oluşması önemli bir gelime olarak görülmektedir. İşgörenlerin maddi olarak tatmin edilmesinin yanı sıra, işgörenlerine güvenerek, fikirlerini alarak, onları örgütün temel unsuru olarak görmeleri zamanla işgörenlerin örgüte karşı bir duygusal bağ ile bağlanmalarını katkı yapmaktadır.

Örgüte karş1 duygusal bağl1lık gösteren işgörenler örgütün temel unsuru olmaktan ve manevi açıdan kendisini değerli hissetmelerinden kaynaklanmaktadır. Duygusal anlamda bağl1lığı yüksek işgörenler örgütün çıkarlarını korumak adına daha fazla çaba sarf edeceğinden örgütler tarafından daha çok değerli hale gelmektedirler. Örgüte bağlı kalmanın kendisine para, kıdem, sosyal hak, emeklilik hakkı, tazminat vb. maddi açıdan yarar sağlayacak olan kazanımları göz önünde bulunduran işgörenlerin bağlılık türü ise devam bağlılığı olarak tanımlanmaktadır. Örgütten ayrılacağında bu kazanımların da yok olacağını düşündüklerinden örgütte 
kalmanın kendi yararına olacağını düşünen işgörenlerin ise devam bağlılığının yüksek olduğu görülmektedir (Özdemir ve Yayli, 2014: 49).

İşgörenin, örgütün amaçlarına ulaşabilmesi için emek harcaması ve örgütte devamlılığının sağlaması için örgüte bağlılık duyması gerekliliği, işgörenlerin tatmin edilmesinin öneminin bilinmesi gerekmektedir. Böylece işgörenler örgütlerini gönüllülük esası ile koruyup kollayarak benimseyeceklerdir. Örgütün yönetimsel amaçları arasında yer alan işgörenin bağlılığının sağlanması hem maddi hem de manevi şekilde sağlanmaktadır. Örgütün kültürü, kimliği, imajı, kullandıkları liderlik tarzları, eğitim ve geliştirme faaliyetlerine kadar etkili olan örgütsel bağll1ık, özellikle manevi açıdan işgörenlerin doyumu ile mümkün olmaktadır (Sevinç ve Şahin, 2012:267). Sevinç ve Şahin'in belirttiği etmenler arasında yer alan örgüt kültürü ve liderlik tarzı, örgütsel bağl1lık konusunda, kendi duygu ve düşüncelerini anlayan, kendisi düşüncelerine değer verdiğini düşündüğü, dürüst davranan ve kendisine güvenen bir lider olması durumunda etkili olmaktadır. Bu tarz bir lider, alanyazında otantik lider olarak tanımlanmaktadır.

Başta Avalio ve Gardner, (2005) ve Karatürk'ün (2015) çalışmaları olmak üzere örgütsel bağl1lığın örgütsel iklimle de ilişkili olduğu yapılan alanyazın çalışması doğrultusunda söylenebilmektedir. Örgütün herhangi bir üyesinin konuşma tarzı ya da duruşu, örgüt iklimi hakkında bilgi sahibi olunmasını sağlamaktadır. Ayrıca, işgörenlerin ve örgütlerin hayatta kalabilmeleri, kabul görülmeleri ve başarılı olabilmeleri için gerekli olan örgütsel iklimin, örgütsel bağl1lığın sonucunda ne boyutta olduğu bilinmektedir. Bir örgütün örgütsel iklimini örgütlerde liderlik türleri gibi örgütsel iklim de değişiklik göstermektedir (Avalio ve Gardner, 2005: 365). Teorik anlamda örgütsel uyum, tatmin, performans ve örgütsel vatandaşlık davranışları ile de ilgilidir. Bu tür davranışlarla ilişkilendirilen ve desteklenen bağlılık, daha güçlü bir hal alacağından örgütlerin vazgeçemeyeceği bir unsur olarak görülmektedir. Bundan dolayı liderlerin, işgörenlerinin örgütleriyle bütünlük sağlayabilmek adına daha fazla emek harcamaları gerekmektedir (Karatürk, 2015: 44).

İşgörenlerin örgüte bağlılık düzeyine göre elde edilen sonuçlarının çoğu davranışsal boyuttadır. Motive edilme, tatmin edilme ve işten ayrılmama isteği ve bağlılık arasında olumlu, iş değiştirme, sinizm, işten ayrılma ile bağl1lık arasında olumsuz yönde bir ilişki olduğu araştırmacılarca belirtilmiştir (Yağc1, 2007:119). Örgüt kültüründe, işgörenlerine örgütün bir parçasıymış gibi görmeleri işgörenlerin nasıl davranacaklarına da etki edeceğinden, işgörenlerin kendilerini geliştirmelerine yönelik zam, kıdem, ödüllendirme, eğitim ve geliştirme de dâhil olmak üzere onları örgüte daha çok bağlayacak faaliyetler de bulunmaları gerekmektedir. Her örgütün işgörenleri elde tutma çabaları farklıdır. Özellikle işten ayrılma niyeti olan işgörenlerin bunu işten ayrılma davranışına dönüştürmeden önce örgüte olan güvenlerinin arttırılması ve örgütün de bunun için çeşitli faaliyetlerde bulunması hem işgörenlerin hem de örgütün yararına bir davranış olacaktır. İşgören temini ile ilgili problemi olmayan örgütler için bu durum söz konusu olmayabilir (Çetin, 2011: 63; Uçkun vd., 2013:72).

Özgüven sahibi, iyi niyetli, güvenilir, vizyon sahibi, işgörenlerinin eksiklerini ve kapasitelerini kolaylıkla belirleyebilen otantik liderlerin bu ve benzeri özelliklere sahip olmaları doğrudan işgörenlerin örgüte olan bağl1lık düzeylerini de etkilemektedir. İşgörenlerini kendilerinden bile daha iyi tanıyan liderler, iş yüklerini, tatmin düzeylerini, kapasitelerini bilip ona göre davrandığı ve işgörenleri ile sürekli iletişim halinde olduğu için örgütsel bağlılıklarını da etkilemiş olacaktır (Yaşbay, 2001: 163; Büyükbeşe vd. 2019: 201).

\section{PSİKOLOJİK SERMAYE}

Tüm üretim faktörleri ve bilginin kullanılabilir hale gelmesinin insan kaynağ sayesinde gerçekleştiği geniş bir şekilde kabul görmektedir. Rekabete dayalı günümüz iş dünyasında çalışmak zorunda olan işgörenlerin; stresli, zorlu işyeri koşulları ve rakip işgörenler gibi unsurlardan dolayı psikolojik durumlarının dengede tutulması ve dikkatli bir biçimde ele alınması örgütler açısından git gide zorunlu bir hal almaktadır. Zira işgörenlerin özel hayatları da dâhil olmak üzere yaşadıkları problemlerin, iş memnuniyeti ve performans düzeylerini etkilediği bilinen bir gerçektir (Aydın-Tükeltürk ve Karalar, 2015: 256). Bu çerçeveden bakıldığında örgütler, işgörenleri için hem iş hem özel yaşamlarını dengede tutacak koşulları hazırlamaları adına, kendilerini tanımaya olanak verecek çalışma koşullarını hazırlamalıdır. Bu durum modern yönetim anlayışının zorlu bir noktasıdır.

İşgörenlerin bireysel anlamda gelişmelerini ve performanslarını arttırmaya yönelik olan psikolojik bir kaynak olan psikolojik sermaye, aynı zamanda örgütsel anlamda da entelektüel sermaye kaynaklarına paralel bir şekilde, işgörenlerin verimliliklerinin ve performansının da artmasına katkı sağlayan bir sermaye unsurudur. Başka bir deyiş̧le işgörenlerin kim olduklarına ve kim olacaklarına dair bilgiler sunan geliştirilmeye açık bir olgu olarak tanımlanmaktadır (Luthans vd., 2005). Bu, işgörenlerin kendilerini hem bireysel hem de örgütsel amaçları gerçekleştirmeye hazır hale getirilmesi konusunda gerçekleştirilmiş faaliyetler arasında öncelikli olarak yerini almış olacaktır. 
Erkuş ve Fındıklı’ya (2013: 2) göre psikolojik sermaye; öz yeterlilik, iyimserlik, umut ve dayanıklılık olmak üzere dört temel alt boyuttan oluşmaktadır. Öz yeterlilik; işgörenin karşılaştığı sorunların çözümünde kendi bilgi beceri ve yeteneğine güvenmesi (Çoban, 2013:20), iyimserlik; işgörenin amaçlarına ulaşabilmesi için istikrarlı bir şekilde sarf ettiği çabalar sonucunda her şeyin yoluna gireceğini ve emeklerinin karşıllğını alacağını düşünmesi (Keleş, 2011: 347), umut; işgörenin amaçlarını gerçekleştirirken pozitif bir motivasyon ile karşılaşılabilecek engellerin üstesinden kolaylıkla gelinebileceğine inanması (Akçay, 2011: 126), dayanıklılık ise; işgörenin karşılaşabileceği zorluklar ve başarısızlıklar sonucunda dirayetli bir yapıya bürünmesi olarak tanımlanmaktadır (Çoban, 2013:21).

Otantik liderlik için büyük öneme sahip olan psikolojik sermaye, performansın geliştirilmesinde önderlik etmektedir. İzleyenlerini psikolojik sermayelerinin güçlendirmeye yönelik teşvik eden liderler onlara rol model olarak öncülük etmektedirler. Topaloğlu ve Özer (2014:162) birçok araştırma sonucunda otantiklik özelliğine sahip liderler ile işgörenlerin psikolojik sermayelerinin düzeyleri arasında pozitif ve anlamlı ilişkiler olduğunu ifade etmektedir.

Psikolojik sermayenin örgüt yaşamındaki yansıtıcısı olarak görülen örgütsel davranış yaklaşımı, pozitif sermaye kavramının da ortaya çıkmasına katkı sağlamıştır. Konu ile ilgili yapılan çalışmaların çoğu, psikolojik sermayenin bireysel ve örgütsel boyutları ile geliştirilmesi gereken önemli bir kavram olduğundan bahsetmektedir. Psikolojik sermaye, genel olarak, işgörenlerin şuanda kim olduklarından ziyade, gelecekte kim olacaklarıyla alakalı bir kavramdır (Erkmen ve Esen, 2013: 23). Otantik liderler, karşısındakini tanıma, anlama ve fikirlerini dikkate alma özellikleri ile işgörenlere kendini tanıma ve gelişimleri adına neler yapabileceklerini gösterebilmektedir. İşörenlerin bu anlayışı firsata çevirme ve gelişimleri ile birlikte artan performans sergilemeleri gözlemlenebilecektir. Her işgören artı ve eksilerini gösteren, gelişim yollarını gösteren ve fikirlerine değer veren, başarılı bir işgören profili yanı sıra kendisinden değerli bir insan kaynağ 1 olarak bahsedecek bir yönetici ister.

Psikolojik sermayenin revize edilebilir olması yönetilirken de örgüt ve işgören arasında önemli sonuçlar elde edilmesine katkı sağlamaktadır. Geçmişte örgüte olan bağlılık pek önemsenmese de günümüzde önemli hale gelmiş olması, işgörenlerin örgüt amaç ve hedeflerine önemli katkı sağladıkların bilincinde olunmasıdır. Ayrıca, işgörenlerin tatmin edilmesi müşteri tatmininin de elde edilmesine katkı sağlamaktadır. Bu nedenle rekabet avantajı elde etmek isteyen örgütlerin işgörenlerinin örgütsel bağlılık düzeylerini arttırmaları için psikolojik sermayelerine de önem vermelerinin önemli olduğunu bilmeleri ve kendilerine has stratejiler geliştirmeleri gerekmektedir (Ocak vd., 2016: 3).

İşörenler arasında pozitif bir iklimin oluşmasını destekleyen otantik liderliğin, işgörenlerin psikolojik anlamdaki kapasitelerini geliştirmeleri örgüt yararına olan bir durumdur. Oluşturulan bu pozitif iklimin yanı sıra, istenilen performansın oluşmasına da katkı sağlamaktadır. Örgütlerin rekabet etmelerinde vazgeçilmez bir unsur olarak görülen psikolojik sermaye, örgütsel bağlılığın elde edilmesinde de büyük önem arz etmektedir (Büyükbeşe vd., 2019: 201-203).

Takipçilerinin gelişimine katkıda bulunma ve onları moral motivasyon olarak üst seviyelere çıkarma otantik liderlerin başlıca özellikleri arasındadır. Bu durum onların dürüstlük, güven verebilme ve şeffaf olabilmeleri ile takipçilerini de desteklemelerine öncü olmaktadır. Yine örgüt kültürünü paylaşımcı ve psikolojik sermayeyi geliştirici bir ortam haline getirmeyi amaçlamaktadırlar (Topaloğlu ve Özer, 2014:162). Örgüte bağl1 gerçekleşen bir takım niteliklerin varlığ ya da yokluğu her bir işgörenin çalıştı̆̆ı örgüte ilişkin tutumlarını ve işgörenin örgütüne karşı bağl1lığını etkiler (Dağdeviren, 2007: 84). Bireysel gelişimi teşvik eden otantik liderler hem kendileri hem de takipçilerinin örgüt içerisinde olumlu tutum sergilemelerine katk1 yapmaktadırlar. Bu durumdan dolayı bu tarz liderler örgüt içerisinde nasıl algılandıklarının da farkındadırlar (Demirağ, 2015: 276). Başka bir ifade ile otantik liderlik tarzı örgüte ve örgüt çalışanlarına, gelişim ve farkındalık anlamında, hizmeti amaçlamakta ve sürekli bireylerin ihtiyaçlarını ön planda tutmaktadırlar (Karahan, 2008:150).

\section{METODOLOJI}

\subsection{Araştırmanın Amacı, Önemi ve Katkıları}

Günümüz koşullarında örgütlerin rekabet avantajı elde edebilmeleri, işgörenlerini geliştirmeye yönelik çalışmaların arttırılması ve işgörenlerin örgütsel bağl1lık düzeylerinin arttırılması ile mümkün olmaktadır. Örgütsel bağl1lıktan bahsedilebilmek için işgörenleri anlayan, onların fikirlerine önem veren, kendilerini örgütün bir parçası gibi gören ve onlara rol model olan bir lidere ihtiyaç duyulmaktadır.

$\mathrm{Bu}$ araştırmayla otantik liderliğin hem psikolojik sermaye aracılığı ile örgütsel bağl1lı̆ga etkileri ile ilgili bir araştırma olup liderlik yazınına katkı sağlamayı amaçlamaktadır. Çalışmada ilk olarak, yapılan alanyazın taraması sonucunda kuramsal çerçevesi oluşturulmuş bunun sonucunda da hipotezler belirlenmiştir. Çalışmada ilişkinin 
ölçülmesinin yanı sıra otantik liderliğin örgütsel bağllık ve psikolojik sermaye aracılı̆̆ ile etkileri konusu ile ilgili olarak çalışmaların sınırlı olmasından dolayı elde edilecek sonuçların alanyazına zenginlik katacağı ve örgütlere rekabet üstünlüğü sağlamada büyük katkılar elde edeceği düşünülmektedir. Otantik liderlik, örgütsel bağl1lık ve psikolojik sermaye üzerinde büyük bir etkiye sahiptir. Otantik liderliğin psikolojik sermaye aracıllı̆̆ ile örgütsel bağlılığa etkileri ve Denizli ilinde tekstil endüstrisinin gelişmesinde psikolojik sermayenin aracilık rolünün önemi araştırılmıştır. Otantik liderliğin psikolojik sermaye aracılı̆̆ı ile örgütsel bağl1lığa etkileri ile ilgili hipotezler ayrı ayrı oluşturulmuştur. Bununla birlikte psikolojik sermayenin aracılık rolü olup olmadığı üzerine bir model oluşturulmuştur.

Çalışmanın konu ve uygulama kapsamı doğrultusunda alt amacını oluşturan demografik özelliklerle (cinsiyet, yaş, eğitim durumu, görev alanı) çalışmanın ana konusunu (aracılık rolüne bakılmasına rağmen) oluşturan değişkenlerden psikolojik sermaye üzerindeki algı farklılıklarını ölçmek amacıyla H1 ve H1'in alt hipotezleri oluşturulmuştur. Otantik liderlik ve örgütsel bağl1lık algısında demografik değişkenlerin farklılık ortaya koyup koymadığı ile ilgili çalışmaların alanyazında fazlasıyla yer alması sebebi ile incelenmemiştir.

Işkın ve Kaygın'ın (2016) ve Yaşbay'ın (2011), otantik liderlik ve örgütsel bağlılığı alt boyutlarıyla incelerken aralarında ilişki olduğu sonucuna vardığı çalışmaları doğrultusunda, Öztürk-Çiftçi’nin (2018), otantik liderlik algısında psikolojik sermayenin ne derecede önemli olduğuyla ilgili yapılan çalışması doğrultusunda ve Büyükbeşe vd.'nin (2019), otantik liderlik ile örgütsel bağlılık arasındaki ilişki ve etkilerinin yanı sıra psikolojik sermayenin aracılık rolü olduğu sonucu doğrultusunda H2, H3, H4, H5, H6, H7 ve H8 hipotezleri oluşturulmuştur.

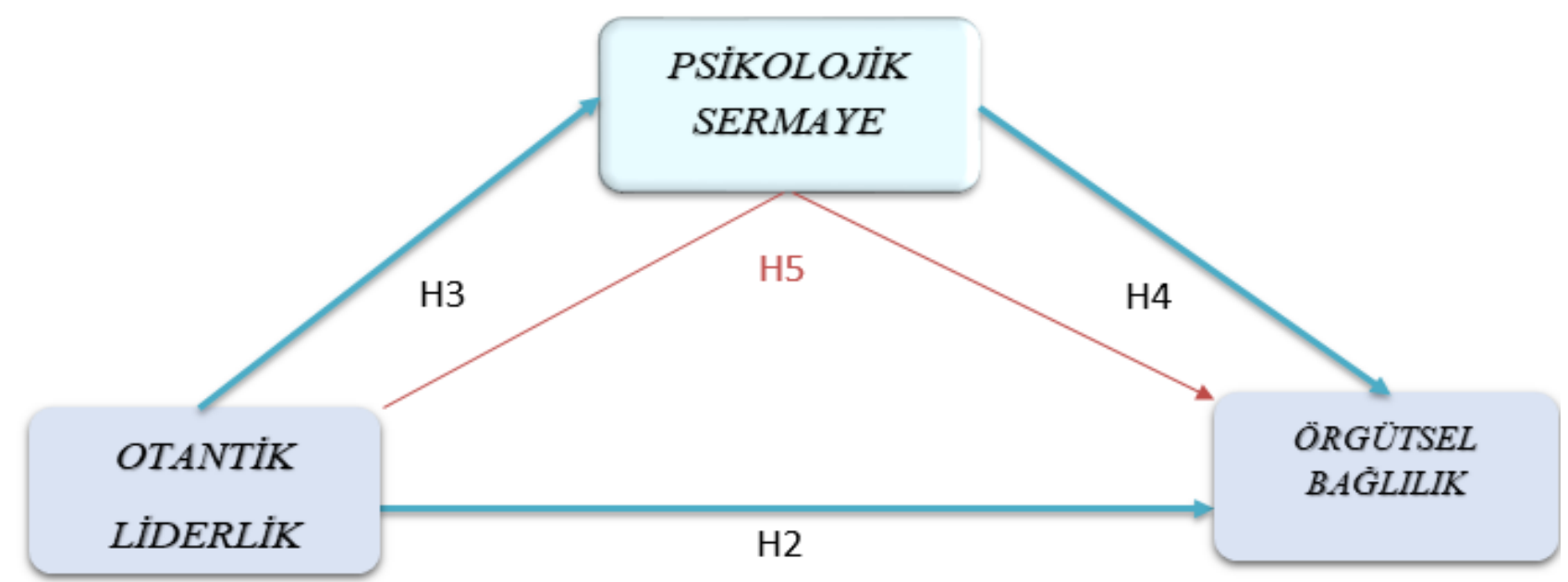

H1: Demografik değişkenler psikolojik sermaye algılanmasında istatistikî olarak anlamlı farklar ortaya koymaktadır.

H1 a: Cinsiyet, psikolojik sermaye algılanmasında istatistikî olarak anlamlı farklar ortaya koymaktadır.

$\mathrm{H} 1_{\mathrm{b}}$ : Yaş, psikolojik sermaye algılanmasında istatistikî olarak anlamlı farklar ortaya koymaktadır.

$\mathrm{H} 1_{c}$ : Eğitim durumu, psikolojik sermaye algılanmasında istatistikî olarak anlamlı farklar ortaya koymaktadır.

H1 $1_{\text {d }}$ Görev alanı, psikolojik sermaye algılanmasında istatistikî olarak anlamlı farklar ortaya koymaktadır.

H2: Otantik liderlik (OL), örgütsel bağlılık (ÖB) üzerinde pozitif ve anlamlı etkiye sahiptir.

H3: Otantik liderlik (OL), psikolojik sermaye (PS) üzerinde pozitif ve anlamlı etkiye sahiptir.

H4: Psikolojik sermeye (PS), örgütsel bağlılık (ÖB) üzerinde pozitif ve anlamlı etkiye sahiptir.

H5: Otantik liderliğin(OL), örgütsel bağlılık (ÖB) üzerindeki etkisinde, psikolojik sermayenin (PS) aracilık rolü vardır.

H6:Otantik liderlik(OL) ve örgütsel bağlıık(ÖB) arasında istatistik olarak pozitif ve anlamlı ilişki vardır.

H7: Otantik liderlik(OL) ve psikolojik sermaye (PS) arasında istatistik olarak pozitif ve anlamlı ilişki vardır.

H8: Psikolojik sermaye (PS) ve örgütsel bağlılı(ÖB) arasında istatistik olarak pozitif ve anlamlı ilişki vardır.

\subsection{Araştırmanın Evreni ve Örneklem}

$\mathrm{Bu}$ araştırmanın evreni Denizli ili organize sanayi bölgesinde faaliyet gösteren tekstil işletmeleri çalışanlarıdır. Örgütteki işgören sayısı yaklaşık olarak 350 kişidir. Araştırmanın örneklemi ise evreni temsil 
edecek şekilde tesadüfi olarak belirlenen bir tekstil işletmesi çalışanlarıdır. Araştırmada, örgüt yöneticileri ile gerçekleştirilen görüşmeler sonucunda, 300 işgörene anket dağıtılmıştır. Dağıtılan anketlerin 250'si geri dönmüş, yanlış ve eksik doldurulan 34 anket değerlendirmeye alınmamış ve sonuç olarak 216 anket analiz için kabul edilmiştir.

\subsection{Veri Toplama Aracı ve Ölçekler}

Araştırma doğrultusunda oluşturulan hipotezlerin test edilebilmeleri için amaciyla anket yöntemi kullanılmış̧ır. Anket sorularının oluşturulmasında otantik liderlik ile ilgili olan sorular Tabak ve Polat (2012)'ın Tekirdağ'da üretim sektöründe faaliyet gösteren “Otantik Liderlik Ölçeği: Güvenilirlik ve Geçerlilik Çalışması" konulu çalışmasından, örgütsel bağlllık ile ilgili sorular Jaworski ve Kohli (1993) tarafından geliştirilen ve Şeşen (2010) tarafindan "Öncülleri ve Sonuçları ile Örgüt İçi Girişimcilik: Türk Savunma Sanayinde Bir Araştırma " konulu çalışmasında Türkçe'ye uyarlanmıştır. Son olarak psikoloji sermaye ile ilgili sorular ise Firestone (2010)'un "Measuring Psychological Capital in Non-Profit Social Service Organizations" konulu çalışmasından çevrilip sektörde uzman kişilerin, akademisyenlerin görüşleri alınıp tekstil işletmelerine uyarlanarak pilot uygulama için hazır hale getirilmiştir.

Çalışmanın uygulama kısmını tamamlamak için üç bölümden oluşan bir anket formu geliştirilmiştir. Anketin birinci bölümünde, otantik liderliğin yer aldığ 15 değişkenden oluşan sorular bulunmaktadır. İkinci bölümünde, aracılık rolünün araştırıldığı psikolojik sermaye ile ilgili 24 değişken yer almaktadır. Üçüncü bölümde ise, örgütsel bağl1lıkla ilgili 6 değişen bulunmaktadır. Yöneticilerin ve çalışanların, bu değişkenleri 5'li Likert ölçeğine göre yanıtlamaları istenmiştir (1: Kesinlikle Katılmıyorum, 2: Katılmıyorum, 3: Ne Katılıyorum Ne Katılmıyorum, 4: Katılıyorum, 5: Kesinlikle Katılıyorum). Anketin son bölümünde ise demografik bilgiler ile ilgili sorular bulunmaktadir.

Tablo 1: Likert Tipi Ölçeklerde Güvenilirlik (Araştırma Uygulaması)

\begin{tabular}{|l|l|l|}
\hline Ölçekler & Cronbach's Alpha & İfade Sayısı \\
\hline Otantik Liderlik &, 925 & 15 \\
\hline Psikolojik Sermaye &, 967 & 24 \\
\hline Örgütsel Bağlıık &, 756 & 6 \\
\hline
\end{tabular}

Bu sonuçlara göre (Tablo 1 ) anketin ölçeklerinden otantik liderlik, psikolojik sermayenin güvenirliliği $\alpha \geq$ .9'a göre mükemmel boyuttadır. Örgütsel bağlılı̆̆ın güvenirliliği ise $.8>\alpha \geq .7$ 'ye göre kabul edilebilir boyuttadir.

\subsection{Araştırmanın Bulguları}

Anketi değerlendirmeye alınan 216 katılımcının 158'ü $(\%$ 73,1) erkeklerden, 58'i $(\% 26,9)$ bayanlardan oluşmaktadır. Çalışanların 18'i (\%8,3) 18-24 yaş aralığında, 72'si (\%33,3) 25-34 yaş aralığında, 78'i (\%36,1) 35-44 yaş aralığında ve 48'i $(\% 22,2)$ ise 45 yaş ve üzerindedir. Çalışanların 77 'si $(\% 35,6)$ ilköğretim, 97'si $(\% 44,9)$ lise, 38 'i $(\% 17,6)$ lisans, 4'ü $(\% 1,9)$ lisansüstü mezunudur. Tekstil işletmelerindeki çalışanlar üzerinde yapılan bu çalışamaya katılanların 9'u (\%4,2) üst düzey yönetici, 17 'si $(\% 7,9)$ orta düzey yönetici, 10'u (\%4,7) alt düzey yönetici ve 180 'i $(\% 83,3)$ ise yönetici olmayan çalışanlardan oluşmaktadır. Analizler yapılan normallik testi doğrultusunda $P$ değeri 0,05 'ten büyük olduğu ve homojen dağılmadığ için Mann-Whitney ve Kruskal - Wallis testi ile yapılmıştır. 
Tablo 3: Demografik Değişkenlere Göre Psikolojik Sermayenin Algılanmasına Yönelik Farklıık Testi

\begin{tabular}{|c|c|c|c|c|c|c|}
\hline & Psikolojik Sermaye & $\begin{array}{l}\text { Kişi } \\
\text { Sayıs } \\
\text { (N) }\end{array}$ & Ort. & $\begin{array}{l}\text { Std. Hata } \\
\text { Ort. }\end{array}$ & Test & $\mathbf{P}$ \\
\hline \multirow[t]{2}{*}{ Cinsiyet } & Erkek & 158 & 97,3101 & 1,46736 & \multirow[t]{2}{*}{1388} & \multirow[t]{2}{*}{,601 } \\
\hline & Kadın & 58 & 94,6724 & 1,46736 & & \\
\hline \multirow[t]{4}{*}{ Yaş } & $18-24$ & 18 & 81,4444 & 6,66089 & \multirow{4}{*}{ 12,007 } & \multirow{4}{*}{, 007} \\
\hline & $25-34$ & 72 & 94,1389 & 2,60907 & & \\
\hline & $35-44$ & 78 & 98,0256 & 2,25364 & & \\
\hline & $45+$ & 48 & 103,6667 & 2,48993 & & \\
\hline \multirow{4}{*}{$\begin{array}{l}\text { Eğitim } \\
\text { Durumu }\end{array}$} & İlköğretim & 77 & 94,7662 & 2,55827 & \multirow{4}{*}{10,382} & \multirow{4}{*}{,016 } \\
\hline & Lise ve dengi & 97 & 93,9897 & 2,28065 & & \\
\hline & Lisans & 38 & 106,1053 & 2,40252 & & \\
\hline & Lisansüstü & 4 & 105,0000 & 6,49359 & & \\
\hline \multirow{4}{*}{$\begin{array}{l}\text { İş } \\
\text { Bölümü }\end{array}$} & Üst Düzey Yönetici & 9 & 107,4444 & 7,84239 & \multirow{4}{*}{8,909} & \multirow{4}{*}{,031 } \\
\hline & Orta Düzey Yönetici & 17 & 102,5294 & 4,49683 & & \\
\hline & Alt Düzey Yönetici & 10 & 106,3000 & 4,56082 & & \\
\hline & Yönetici Değil & 180 & 94,9611 & 1,62528 & & \\
\hline
\end{tabular}

Mann-Whitney U testi sonucunda cinsiyet, eğitim ve geliştirme puanları $(\mathrm{p}=0,601>0,05)$ arasında anlamlı fark ortaya koymamaktadır. Buna göre, erkek katılımcıların puan ortalaması ile kadın katılımcıların puan ortalamaları birbirine yakın veya aynıdır. Bu sonuçlara göre, "Cinsiyet, psikolojik sermaye algılanmasında istatistikî olarak anlamlı farklar ortaya koymaktadır $\left(\mathrm{H}_{\mathrm{a}}\right)$ " olarak kurulan hipotez kabul edilmemiştir.

Kruskall Wallis testi sonucunda yaş, psikolojik sermaye puanları arasında ( $\mathrm{p}=0,007<0,05$ olduğundan) anlamlı fark ortaya koymaktadır. Buna göre 45 yaş ve üzeri katılımcıların diğer yaş aralıklarındaki çalışanlara göre daha fazla puan ortalamasına sahip olduğu ve test sonucunda anlamlı bir fark tespit edilmiştir. Bu sonuçlara göre "Yaş, psikolojik sermaye algılanmasında istatistikî olarak anlamlı farklar ortaya koymaktadır $\left(\mathrm{H} 1_{\mathrm{b}}\right)$ " olarak kurulan hipotez kabul edilmiştir.

Eğitim durumu, psikolojik sermaye puanları arasında ( $p=0,016<0,05$ olduğundan) anlamlı fark ortaya koymaktadır. Buna göre lisans mezunu katılımcıların diğer mezun katılımcılara göre daha fazla puan ortalamasına sahip olduğu ve test sonucunda anlamlı bir fark tespit edilmiştir. Bu sonuçlara göre "Eğitim durumu, psikolojik sermaye algılanmasında istatistikî olarak anlamlı farklar ortaya koymaktadır $\left(\mathrm{H} 1_{\mathrm{c}}\right)$ " olarak kurulan hipotez kabul edilmiştir.

İş bölümü, psikolojik sermaye puanları arasında $(\mathrm{p}=0,031<0,05$ olduğundan) anlamlı fark ortaya koymaktadır. Buna göre üst düzey yöneticiler diğer katılımcıların puan ortalamalarına göre daha fazla puan ortalamasına sahip olduğu ve test sonucunda anlamlı bir fark tespit edilmiştir. Bu sonuçlara göre "Görev alanı, psikolojik sermaye algilanmasında istatistikî olarak anlamlı farklar ortaya koymaktadır $\left(\mathrm{H} 1_{\mathrm{d}}\right)$ " olarak kurulan hipotez kabul edilmiştir.

Psikolojik sermaye değişkeninde, analiz edilen 4 alt hipotez sonucunda, 3 hipotez kabul edilmiş ve 1 hipotez reddedilmiştir. Bu sonuçlara göre, demografik değişkenler psikolojik sermayeyi \%75 açıklamaktadır. 
Tablo 4: Ölçekte Yapılan Değişiklikler

\begin{tabular}{|l|c|c|}
\hline Ölçekler & $\begin{array}{l}\text { İfade } \\
\text { Sayısı }\end{array}$ & $\begin{array}{l}\text { Çıkarılan } \\
\text { İfade Sayısı }\end{array}$ \\
\hline OL & 15 & 11 \\
\hline PS & 24 & 13 \\
\hline ÖB & 6 & 2 \\
\hline
\end{tabular}

Kullanılan ölçeklerin geçerliliğini test etmek amacı ile SPSS AMOS 21 programı kullanılarak tüm ölçekler için tek faktörlü doğrulayıcı faktör analizi yapılmıştır. Ölçeklerin geçerliliklerinin testi için oluşturulan ölçüm modellerinin sahip oldukları uyum değerleri kabul edilebilir sınırlar içinde olmadığından dolayı programın önerdiği düzenlemeler yapılmıştır. Bu düzenlemeler sonucunda ölçekte yapılan değişiklikler Tablo 4 'te, uyum değerleri ise Tablo 6'da gösterilmiştir.

\section{Tablo 5: Yapısal Eşitlik Modellerinin Katsayıları}

\begin{tabular}{|l|l|l|l|l|}
\hline Değişkenler & Standardize ( $\beta)$ & Standart Hata & $\mathbf{P}$ & $\mathbf{R}^{\mathbf{2}}$ \\
\hline OL-PS & 1,09 & 0,044 & $* * *$ & 0,817 \\
\hline OL-ÖB & 1,04 & 0,490 & $* * *$ & 0,586 \\
\hline PS-ÖB & 0,52 & 0,038 & $* * *$ & 0,393 \\
\hline
\end{tabular}

Tablo 5'te verilen regresyon analizinde otantik liderliğin psikolojik sermaye (model 1) üzerine, otantik liderliğin örgütsel bağl1lık (model 2) üzerine, psikolojik sermayenin örgütsel bağl1lık (model 3) üzerine olan etkisi incelenmiştir. Regresyon analizi sonuçları AMOS kullanılarak elde edilmiştir.

Model 1 kapsamında yapılan regresyon analizi sonucunda otantik liderlik ve psikolojik sermaye arasında kurulan model anlamlıdır ( $\mathrm{P}$ değeri $=0,000<0,05$ ). Otantik liderlik, psikolojik sermayeyi pozitif yönde etkilemektedir. Otantik liderlik değişkeni psikolojik sermayeyi \% 81,7 açıklamaktadır ( $R^{2}=0,817$ ). Model 1 testi sonucuna göre çalışmanın "otantik liderlik, psikolojik sermaye üzerinde pozitif ve anlamlı etkiye sahiptir (H3)" hipotezi desteklenmiştir.

Model 2 kapsamında yapılan regresyon analizi sonucunda otantik liderlik ve örgütsel bağl1lik arasında kurulan model anlamlıdır ( $\mathrm{P}$ değeri=0,000<0,05). Otantik liderlik örgütsel bağlılı̆̆ etkilemektedir. Otantik liderlik değişkeni, örgütsel bağl1lı̆̆ $\% 58,6$ açıklamaktadır $\left(R^{2}=0,586\right)$. Model 2 testi sonucuna göre çalışmanın "otantik liderlik, örgütsel bağlılık üzerinde pozitif ve anlamlı etkiye sahiptir (H2)" hipotezi desteklenmiştir.

Model 3 kapsamında yapılan regresyon analizi sonucunda psikolojik sermaye ve örgütsel bağl1lık arasında kurulan model anlamlıdır ( $\mathrm{P}$ değeri $=0,000<0,05)$. Psikolojik sermaye, örgütsel bağl1lı̆̆1 pozitif yönde etkilemektedir. Psikolojik sermaye değişkeni Örgütsel bağlılığ $\% 39,3$ açıklamaktadır ( $\left.R^{2}=0,393\right)$. Model 3 testi sonucuna göre çalışmanın "psikolojik sermaye, örgütsel bağlllık üzerinde pozitif ve anlamlı etkiye sahiptir (H4)" hipotezi desteklenmiştir.

Doğrulayıcı faktör analizi sonrasından AMOS programında yapılan üçlü etki analizlerinde otantik liderlik, psikolojik sermaye ve örgütsel bağlllık arasında pozitif ve anlamlı etkinin elde edilmesi, üç değişken arasında pozitif ve anlamlı ilişki olduğunu göstermektedir. Dolayısıyla "Otantik liderlik(OL) ve örgütsel bağl11ı(ÖB) arasında istatistik olarak pozitif ve anlamlı ilişki vardır." (H6), "Otantik liderlik(OL) ve psikolojik sermaye (PS) arasında istatistik olarak pozitif ve anlamlı ilişki vardır." (H7) ve "Psikolojik sermaye (PS) ve örgütsel bağl1lık(ÖB) arasında istatistik olarak pozitif ve anlamlı ilişki vardır." (H8) hipotezleri desteklenmektedir. 
Şekil 1'de belirtilen Otantik Liderliğin Psikolojik Sermaye aracılığı ile Örgütsel Bağlılığın etkileri Modeli aşağıdaki gibidir;

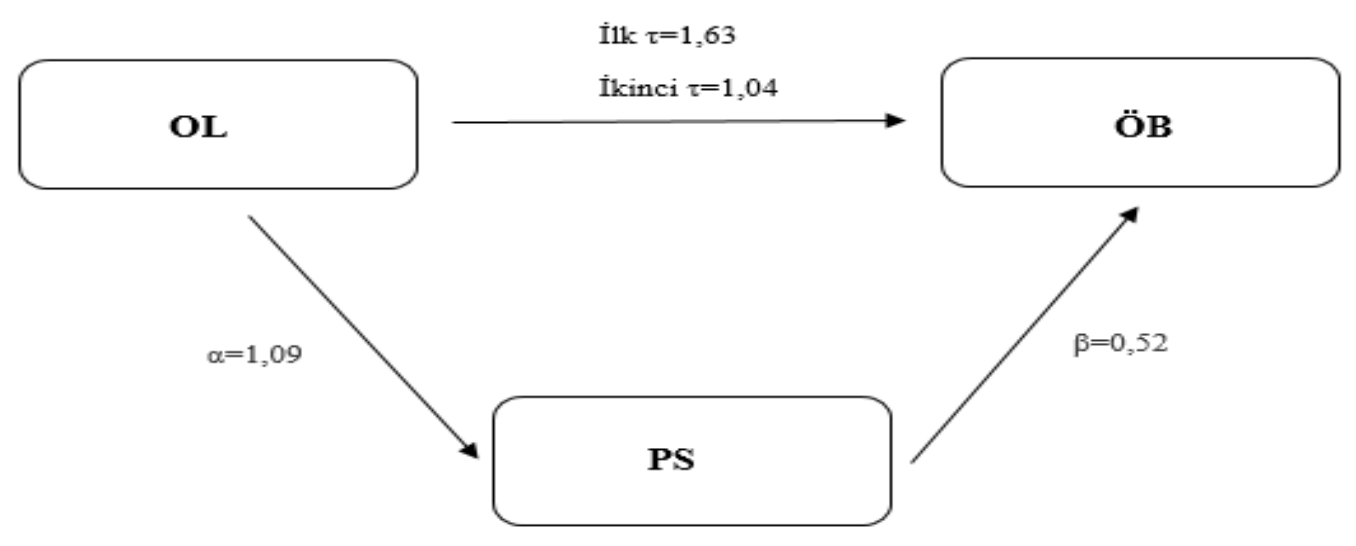

\section{Şekil 1: Otantik Liderliğin Psikolojik Sermaye aracılığı ile Örgütsel Bağılığın etkileri Modeli}

Otantik liderliğin (OL), örgütsel bağlılık (ÖB) üzerinde anlamlı ve pozitif ilişkisinin olduğunun yanı sıra otantik liderliğin (OL) ve örgütsel bağlılık arasında psikolojik sermayenin (PS) aracılık rolü oynadığı bu modelde $\tau$ ile $\tau^{\prime}$ arasında anlamlı bir azalmanın olduğundan dolayı psikolojik sermayenin, otantik liderlik ve örgütsel bağlılık arasında kısmi aracılık rolü oynadığı söylenebilmektedir $\left(\tau^{\prime}<\tau\right)$. Elde edilen değerler oldukça iyi denebilecek sonuçlar ortaya koyduğundan dolayı modelin uyumu istenilen değerlerde çıkmıştır.

Test sonucuna göre çalışmanın "otantik liderliğin (OL), örgütsel bağlılık (ÖB) üzerindeki etkisinde, psikolojik sermayenin (PS) aracılık rolü vardır (H5)" hipotezi desteklenmiştir.

Tablo 6: Şekil 1'e İlişkin Uyum İyiliği Değerleri

\begin{tabular}{|l|l|l|l|l|}
\hline Uyum iyiliği değerleri & $\boldsymbol{\chi} \mathbf{2} / \mathbf{d f}$ & RMSEA & CFI & GFI \\
\hline Yapısal Eşitlik Modeli & 1,834 &, 062 &, 991 &, 967 \\
\hline İyi Uyum Değerleri & $\leq 3$ & $\leq 0,05$ & $\geq 0,97$ & $\geq 0,90$ \\
\hline Kabul Edilebilir Uyum Değerleri & $\leq 4-5$ & $0,06-0,08$ & $\geq 0,95$ & $0,89-0,85$ \\
\hline
\end{tabular}

Yapılan modifikasyon sonucu modelin RMSEA, CFI ve GFI uyum değerlerinin kabul edilebilir, $\chi 2 / \mathrm{df}$ uyum değerlerinin ise, iyi boyutta olduğu (Meydan ve Şeşen, 2011: 37) ve modelin yapısal olarak uygun olduğuna ilişkin yeterli kanıtların sağlandığı gözlemlenmiştir.

\section{SONUÇ VE ÖNERILER}

Otantik lider, takipçilerinin güvenini ve saygısını, onların değerleriyle, etik standartlarıyla ve kişisel görüşleriyle kazanmakta ve aynı zamanda diğerleriyle açık ve işbirlikçi bir çevreyi kolaylaştırmaktadır. Otantik liderlikte önemli olan, liderin kendini, değerlerini, duygu ve hedeflerini tanıyarak, işgörenlerine karş1 samimi bir şekilde ahlaki değerlerini ön planda tutup, karar almadan önce tarafsız bir şekilde irdelemesidir. Böylece, insanların kendi güçlerini inşa etmeleri ve daha pozitif olmaları, örgütün içindeki bağlllık düzeylerinin artması ve pozitif düşünmelerini genişletmeleri için onlara yardımda bulunmaktadırlar.

Çalışmada, önceden belirlenen amaçlar doğrultusunda akademik bir çalışma yürütülmüş ve analizler sonucunda bazı sonuçlara ulaşılmıştır. Anket uygulamasının ortaya koyduğu veriler ışı̆̆ında yapılan analiz ile 8 tane hipotez test edilmiş ve $\mathrm{H} 1_{\mathrm{a}}$ hariç geri kalanların hepsi kabul edilmiştir. AMOS ile yapılan etki analizinde, otantik liderlik ve psikolojik sermaye arasında kurulan, psikolojik sermaye ve örgütsel bağl1lik arasında kurulan, otantik liderlik ve örgütsel bağlılık arasında kurulan pozitif ve anlamlı etkiye sahip olduğu sonucuna varılarak modelde bulunan 3 hipotez kabul edilmiştir.

Tablo 3'teki bulgulara bakıldığında cinsiyet psikolojik sermayenin algılanmasında fark ortaya koymamaktadır. Bunun en önemli nedenleri arasından günümüz koşullarında erkek işgörenler ile kadın işgörenler arasında, bilgi, beceri, yetenek, eğitim ve çalışma koşullarında bir farkın olmaması gösterilebilir. Karatürk (2015), "Otantik Liderlik ve Psikolojik Sermaye Arasındaki Iliş̧kiye Yönelik Bir Alan Araştırması" üzerine İstanbul'da bulunan elektronik sektöründe dünyanın önde gelen örgütün işgörenlerine yaptı̆̆ araştırması ele alındığında, kadın ve erkeklerin psikolojik sermaye algısı arasında anlamlı bir farklılık 
bulunmaktadır. Bu çalışmada Karatürk'ün aksine cinsiyet, psikolojik sermaye algısında anlamlı farklar ortaya koymamaktadır. Çıkan bu farklılığı araştırmaların yapıldığı sosyo-kültürel alan ve sektörel değişkenlerin ortaya koyduğu düşülmektedir. Cinsiyetin farklılık ortaya koymamasına rağmen araştırmada yaş, eğitim durumu ve iş bölümü (pozisyon) psikolojik sermayenin algılanmasında farklılık ortaya koymaktadır sonucuna ulaşı1mıştır. Yaş anlamlı fark ortaya koyarken, ortalama değeri en büyük olan yaş grubu 45 yaş ve üzeridir. Bunun nedenin belirli bir tecrübeyi elde etmiş işgörenlerin psikolojik sermaye alt boyutlarını kavramış ve kendilerini değerlendirdikleri zaman psikolojik sermaye özelliklerine sahip olduğu inancından kaynaklandığ düşülmektedir. Benzer şekilde eğitim durumu da anlamlı fark ortaya koyarken, lisans mezunlarının ortalama değeri en yüksek seviyededir. Bunun yanı sıra lisansüstü mezunların puanı da lisans mezunlarına oldukça yakındır. Az bir farkla düşük olması da sadece 4 lisansüstü mezunun olmasından kaynaklanmaktadır. Eğitim seviyesinin yükselmesi ile birlikte psikolojik sermaye algısı artmaktadır. İş bölümü (pozisyon) psikolojik sermaye algısında da anlamlı farklar ortaya koymaktadır ve üst düzey yöneticilerin ortalama puanı en yüksek seviyededir. Bunun nedeni olarak belirli yetkinliğe ulaşmış ve pozisyon olarak üst düzelere çıkmış bireylerin daha özgüvenli ve farkındalığı artmış bireylerden meydana geldikleri düşünülmektedir.

Leroy vd. (2012), Belçika'da hizmet sektöründe faaliyet gösteren küçük ve orta ölçekli işletmeler üzerine yaptığı çalışmasında, otantik liderlik ile duygusal örgütsel bağlılık arasında bir ilişki ve etki olduğu sonucuna ulaşmaktadır. Gatling vd. (2014), ABD'de turizm eğitimi alan ve su sektörde çalışan öğrenciler üzerine yaptığı çalışmasında, otantik liderlik ile örgütsel bağl1lık arasında pozitif yönlü bir ilişki olduğu sonucuna ulaşılmaktadır. Jensen ve Luthans (2006), işletmelerini yeni kuran girişimciler üzerine yaptıkları çalışmalarında, girişimcilerin genel psikolojik sermaye seviyesi, gerçek liderlik algılarıyla olumlu yönde ilişkili olduğu sonucuna ulaşmaktadırlar. Rego vd. (2015), Portekiz devlet üniversitesinde çalışan öğrenciler üzerine yaptığı çalışmasında, otantik liderliğin örgütsel bağl1lı̆̆ ve pozitif psikolojik sermayeyi ve örgütsel bağlılığın pozitif psikolojik sermayeyi etkilediği sonucuna ulaşılmaktadır. Buna ek olarak da pozitif psikolojik sermayenin otantik liderliğin örgütsel bağlılığı etkilerken aracılık rolü oynadığı sonucuna ulaşılmaktadır. İncelenen çalışmalar bu çalışma ile benzerlik göstermektedir.

Tablo 5'teki yapısal eşitlik modellerinin katsayılarına bakıldığında, otantik liderlik, psikolojik sermaye ve örgütsel bağl1lık arasında üçlü etki tespit edilmiştir. Otantik liderlik ve psikolojik sermaye arasındaki etki düzeyi en yüksek seviyededir. Bu durum otantik liderliğin psikolojik sermaye özelliklerini (öz yeterlilik, iyimserlik, umut ve dayanıklılık ) bireylerde daha da kuvvetlendirici bir liderlik tarzı olmasıdır. Daha sonra ise otantik liderliğin örgütsel bağl1lığ yüksek düzeyde etkileme derecesine sahip olduğudur. Bu da psikolojik sermayeyi etkilemesinin açıklandığ 1 gibi, otantik liderlik tarzının işgörenlerde, iş tatmini ve motivasyon düzelerini artıracak nitelikte olması ve sonucunda da örgütsel bağlılığı artırması şeklinde ifade edilmektedir. Üçlü ekti ile birlikte AMOS'ta yapılan analizlerde, şekil 1'de görüldüğü üzere, $\tau$ değerlerinde azalma meydana gelmesi sebebiyle otantik liderliğin örgütsel bağlılık üzerindeki etkisinde psikolojik sermayenin kısmi aracılık rolü oynadığı tespit edilmiştir. Bu durum otantik liderlik tarzının örgütsel bağl11ığına etkileri öncesinde, bireylerin beklentilerini karşılayacakları şimdiki ve gelecekteki durumlarını belirleme konusunda sağladığı kazanımlar ile örgüt içerisinde bir tatmin ve memnuniyet duygusu yaratmış olmasıdır. Bu kazanımlar, işgörenlerin örgüt içerisinde bağlılıklarının artmasına etki eden dolaylı faktörün aslında psikolojik sermaye olduğunu göstermektedir.

Doğrulayıcı Faktör Analizi sonrasında AMOS programında yapılan üçlü etki analizlerinde otantik liderlik, örgütsel bağlılık ve psikolojik sermaye arasında pozitif ve anlamlı bir etkinin tespit edilmesi, aynı zamanda bu üç değişken arasında pozitif ve anlamlı bir ilişki olduğunu da göstermektedir.

Alanyazın incelendiğinde psikolojik sermayenin örgütsel bağlllık üzerinde olumlu etkileri olduğu sonucuna varılmaktadır. Ocak ve arkadaşlarının (2016: 5) yaptığı çalışmada psikolojik sermaye alt bileşenlerinden umut ve dayanıklılıkla örgütsel bağlılık arasında pozitif ve anlamlı bir ilişkinin olduğunun sonucunu ortaya koymuşlardır. Topaloğlu ve Özer (2014: 162) psikolojik sermayenin yüksek iş performansı ile sonuçlanması konusunda otantik liderlik algısını ve varlığının önemini ortaya koymuşlardır. Bu durum psikolojik sermaye ile örgütsel bağlılık arasından pozitif bir ilişkinin varlığı yanı sıra başka faktörün (otantik liderlik) olması gerekliliğini ortaya koymaktadır.

Çalışmanın kısıtlılıklarına rağmen, gelecek çalışmalara 1şık tutması ile birlikte, farklı sektör ve farklı bölgelerde yapılması, elde edilen sonuçların daha genel ifade edilebilir niteliğe taşınmasına ya da farklı sonuçlar ile akademik anlamdaki yeni çalışmaların kapısını açacaktır. 


\section{KAYNAKÇA}

Akçay, V. H. (2012) "Pozitif Psikolojik Sermayenin İş Tatmini ile İlişkisi”, Kahramanmaraş Sütçü İmam Üniversitesi, İktisadi ve İdari Bilimler Fakültesi Dergisi, 2(1), 123-140.

Akgündüz Y. (2012) “Konaklama İşletmelerinde Otantik Liderlik ve Öz Yeterlilik Arasındaki İlişkinin Analizi”, Doktora Tezi, Dokuz Eylül Üniversitesi, Sosyal Bilimler Enstitüsü, İzmir.

Avolio B., Gardner W. (2005) “Authentic Leadership Development: Getting to the Root of Positive forms of Leadership”, Gallup Leadership Institute, College of Business Administration.

Avolio B., Walumbwa F., Weber T. (2009) "Leadership: Current Theories, Research, and Future Directions". Annual Review of Psychology, 60, 421-449.

Aydın-Tükeltürk, Ş., Karalar, S. (2015) "Psikolojik Sermaye.” Derman Küçükaltan, Şule 1091 Aydın Tükeltürk, Güney Çetin Gürkan (Eds.) Örgütsel Davranışta Güncel Konular kitabı içinde (bölüm 15 , sayfa 251-264). Detay Yayınc1lı: Ankara.

Bass B., M., Steidlmeier, P. (1999) “Ethics, Character, and Authentic Transformational Leadership Behavior", The Leadership Quarterly, 10(2), s. 181-217.

Büyükbeşe, T., Çavuşoğlu, S., Okun, O., (2019) Otantik Liderlik ile Örgütsel Bağlılık Arasında Psikolojik Sermayenin Aracılık Rolü: Bingöl Üniversitesi Örneği, Uluslararası Toplum Araştırmaları Dergisi, 10(17), s. 194-225.

Chan, A., Hannah, S. T., Gardner, W. L., (2005) "Veritable Authentic Leadership: Emergence, Functioning, and Impacts", Monographs in Leadership and Management, 3, s. 3-41.

Çoban, A. (2013) "Psikolojik Sermayenin Örgütsel Adalet ve Örgütsel Bağlılık İlişkisi Üzerindeki Rolü”, Organizasyon ve Yönetim Bilimleri Dergisi, 5(2), s. 17-33.

Coşar S. (2011) “Otantik Liderlik Kavramı ve Adılları Üzerine Bir Araştırma”, Yüksek Lisans Tezi, Kara Harp Okulu, Savunma Bilimleri Enstitüsü, Ankara.

Çetin, F. (2011) “Örgütsel Vatandaşlık Davranışlarının Açıklanmasında Örgütsel Bağlılık, İş Tatmini, Kişilik ve Örgüt Kültürünün Rolü’, Yayınlanmamış Doktora Tezi, Ankara Üniversitesi, Sosyal Bilimler Enstitüsü, Ankara.

Öztürk-Çiftçi D. (2018) “Otantik Liderlik Tarzı ve Çalışanların İşe Adanmışlıkları Arasındaki İlişkide Pozitif Psikolojik Sermayenin Aracı Değişken Rolü”, Doktora Tezi, Bolu Abant İzzet Baysal Üniversitesi, Sosyal Bilimler Enstitüsü, Bolu.

Dağdeviren G. E. (2007) “İş Tatmini ve Örgütsel Bağlılık Sigorta Şirketleri Üzerine Bir Uygulama”, Yayınlanmamış Yüksek Lisans Tezi, Atılım Üniversitesi, Sosyal Bilimler Enstitüsü, Ankara.

Demirağ S. (2015) “Otantik Liderlik ve Örgütsel Vatandaşlık Davranışlarının Karşılaştırılması: Öğretmen Adayları”, Journal of Turkish Studies, 10(15), s. 273-288.

Demirel, Y. (2009) “Örgütsel Bağlılığın İç Hizmet Kalitesi Üzerine Etkisi: Kamu ve Özel Sektör Çalışanları Üzerine Bir Araştırma”, Kütahya Dumlupınar Üniversitesi Sosyal Bilimler Dergisi, 23, s. 269-282.

Erkmen T. ve Esen E. (2013) “Psikolojik Sermaye Ölçeğinin Geçerlilik ve Güvenilirlik Çalışması”, Öneri Dergisi, 10(39), s. 23-30.

Erkuş A. ve Fındıklı M. (2013) "Psikolojik Sermayenin İş Tatmini, İş Performansı ve İşten Ayrılma Niyeti Üzerindeki Etkisine Yönelik Bir Araştırma”, İstanbul Üniversitesi İktisadi ve İdari Bilimler Fakültesi İşletme Fakültesi Dergisi, 42(2) s. 302-318.

Firestone, D. J. (2010) "Measuring Psychological Capital in Non-profit Social Service Organizations". University of Nevada, Reno.

Gatling, A., Kang, H. J. A., ve Kim, J. S. (2016). The effects of authentic leadership and organizational commitment on turnover intention. Leadership \& Organization Development Journal, 37(2), s. 181-199.

Gezer, A. (2015) "Otantik Liderlik Davranışlarının İş Tutumlarına Etkisi: Mersin İli Finans Sektöründe Bir Saha Araştırması", Yüksek Lisans Tezi, Toros Üniversitesi, Sosyal Bilimler Enstitüsü, Mersin.

Işkın, Y., Kaygın, E. (2016) “Otantik Liderlik Anlayışının Örgütsel Bağlılık ve Örgütsel Yabancılaşmayla İlişkisi: Mobilya Sektöründe Bir Araştırma”, Bartın Üniversitesi İİB Dergisi, 7(14), s. 619-647.

Jensen, S. M. ve Luthans, F. (2006). Relationship between entrepreneurs' psychological capital and their authentic leadership. Journal of managerial issues, 18(2), s. 254-273.

Karahan, A. (2008) "Hastanelerde Liderlik ve Örgütsel Bağlılık Arasındaki İlişkinin İncelenmesi”, Sosyal Bilimler Dergisi, 1, s. 130-147.

Karatürk, H. E. (2015) “Otantik Liderlik ve Psikolojik Sermaye Arasındaki İlişkiye Yönelik Bir Alan Araştırması”, Yüksek Lisans Tezi, Adnan Menderes Üniversitesi, Sosyal Bilimler Enstitüsü, Aydın.

Keleş, H. N. (2011) "Pozitif Psikolojik Sermaye: Tanımı, Bileşenleri ve Örgüt Yönetimine Etkileri”, Organizasyon ve Yönetim Bilimleri Dergisi, 3(2), s. 343-350.

Kernis M., H. (2003) “Toward a Conceptualization of Optimal Self-Esteem”, Psychological Inquiry, 14(1), s. 1-26.

Keser S.(2013) "İlköğretim Okulu Yöneticilerinin Otantik Liderlik ve Psikolojik Sermaye Özelliklerinin Karşılaştırılması”, Yüksek Lisans Tezi, Yıldız Teknik Üniversitesi, Sosyal Bilimler Enstitüsü, İstanbul.

Keser S., Kocabaş İ. (2014) "İlköğretim Okulu Yöneticilerinin Otantik Liderlik ve Psikolojik Sermaye Özelliklerinin Karşılaştırılması", Kuram ve Uygulamada Eğitim Yönetimi Dergisi, 1(1), s. 1-22.

Leroy, H., Palanski, M. E, ve Simons, T. (2012). Authentic leadership and behavioral integrity as drivers of follower commitment and performance. Journal of Business Ethics, 107(3), s.255-264. 
Loke, C. F. J. (2001) "Leadership Behaviours: Effects on Job Satisfaction, Productivity and Organizational Commitment", Journal of Nursing Management, 9(4), s. 191-204.

Luthans, F., Avolio, B.J., Walumbwa, F.O., Li, W. (2005) "The Psychological Capital of Chinese Workers, Exploring the Relationship with Performance", Management and Organization Review, 1(2), s. 249-271.

Meydan, C. H., Şeşen, H. (2011) "Yapısal Eşitlik Modellemesi (AMOS Uygulamalar1)”, ISBN: 978-605-5437-01-5, Detay Yayıncilık, Ankara

Ocak, M., Güler, M., ve Basım, H.N. (2016) "Psikolojik Sermayenin Örgütsel Bağlılık ve İş Tatmini Tutumları Üzerine Etkisi: Bosnalı Öğretmenler Üzerine Bir Araştırma”, Çankırı Karatekin Üniversitesi İktisadi ve İdari Bilimleri Fakültesi Dergisi, 6(1), s. 113-130.

Öcal, H., Barın, N. (2016) “Otantik Liderlik Davranışlarının İşe Yabancılaşma ile ilişkisi: Bursa İli Dericilik Sektöründe Bir Araştırma”, İş, Güç, The Journal of Industrial Relations and Human Resources, 18(2).

Özdemir, H., Yaylı A. (2014) "Çalışanın Örgütsel Bağlılığı, Performansı ve İşten Ayrılma Niyeti Arasındaki İlişkinin Belirlenmesine Yönelik Bir Araştırma”, Journal of Recreation and Tourism Research (JRTR), 1 (1), s. 48-58.

Rego, P., Lopes, M. P. ve Nascimento, J. L. (2016). Authentic leadership and organizational commitment: The mediating role of positive psychological capital. Journal of Industrial Engineering and Management (JIEM), 9(1), s. 129151.

Sert, Ş. (2015) "Stratejik Liderlik- Çağ- Nema Öğretim İşletmeleri Genel Müdürlüğü Stratejik Liderlik Uygulamaları”, Yüksek Lisans Tezi, İstanbul Gelişim Üniversitesi, Sosyal Bilimler Enstitüsü, İstanbul.

Sevinç İ., Şahin A. (2012) "Kamu Çalışanlarının Örgütsel Bağlılığı: Karşılaştırılmalı Bir Çalışma”, Maliye Dergisi, 162, s. 266-281.

Tabak A., Polat M., Coşar S., Türköz, T. (2010) “Otantik Liderlik Ölçeği; Güvenilirlik ve Geçerlilik Çalışması”, ISGUC The Journal of Industrial Relations and Human Resources, 14(4), s. 89-106

Topaloğlu T. Özer, P. (2014) "Psikolojik Sermaye ile İş Performansı Arasındaki İlişkiye Otantik Liderliğin Düzenleyici Etkisi”, Organizasyon ve Yönetim Bilimleri Dergisi, 6(1), s. 160-172.

Uçkun G., Uçkun S., Demir B., Gültekin A. (2013) “Örgüt Kültürünün Yapısı ve İnsani İlişkiler ile Örgütsel Bağlılık Arasındaki İlişkinin İncelenmesi Kocaeli Üniversitesi İdari Personel Örneği”, Ejovoc (Electronic Journal of Vocational Colleges), 3(3), s. 69-91

Walumbwa, F. O., Avolio B. J., Gardner, W. L., Wernsing, T. S., Peterson, S. J. (2008) “Authentic leadership: Development and Validation of a Theory-based Measure." Journal of Management, 34(1), s. 89-126.

Yağcı, K. (2007) "Meyer-Allen Örgütsel Bağlılık Modeli Yaklaşımıyla Otel İşletmeleri İşgörenlerinin Örgütsel Bağlılık Düzeylerinin Ölçülmesine Yönelik Bir Araştırma”, Dokuz Eylül Üniversitesi, Sosyal Bilimler Enstitüsü Dergisi, 9(3), s. 114-129.

Yaşbay H. (2007) “Otantik Liderlik ve Örgütsel Bağlılık İlişkisi”, Yüksek Lisans Tezi, Dokuz Eylül Üniversitesi, Sosyal Bilimler Enstitüsü, İzmir. 